\title{
Investigating Neurological Manifestations of SARS-CoV-2
}

\author{
Maryam Mozafar $^{1} \cdot$ Seyed Amir Mirmotalebisohi ${ }^{2,3} \cdot$ Marzieh Sameni $^{2,3} \cdot$ Hakimeh Zali $^{4,5}$
}

Received: 20 January 2021 / Accepted: 31 July 2021/Published online: 24 August 2021

(C) The Author(s), under exclusive licence to Springer Science+Business Media, LLC, part of Springer Nature 2021

\section{Dear Editor}

Since the beginning of the COVID-19 pandemic, SARS$\mathrm{CoV}-2$ caused near one hundred million confirmed cases and over two million deaths worldwide, Until 2021 February. Although SARS-CoV-2 primarily targets the human respiratory system, it has also shown neurotropic and neuroinvasive properties. Evidence of neuroinvasion in post-mortem COVID-19 patients has been reported (Reichard et al. 2020; Song et al. 2020). A range of various neurological manifestations is reported so far in SARS-CoV-2 infection, from mild symptoms such as headache, dizziness, impaired consciousness, smell/taste impairment, and neuralgia to more severe complications, including seizures, psychosis, acute ischemic stroke, and acute cerebrovascular diseases (GuadarramaOrtiz et al. 2020; Liu et al. 2020; Valiuddin et al. 2020).

Patients with neurodegenerative disorders who are usually older potentially have a higher risk of developing COVID-19. However, comorbidity, severity, and duration of their neurodegenerative disease are considered more important factors. The morbidity and mortality of COVID-19 in the severe stages of Parkinson's, Alzheimer's, and Huntington's disease might be higher because of respiratory muscle

Hakimeh Zali

hakimehzali@gmail.com; h.zali@sbmu.ac.ir

1 Department of Pharmaceutical Biotechnology, Faculty of Pharmacy, Tehran University of Medical Science, Tehran, Iran

2 Student Research Committee, Department of Biotechnology, School of Advanced Technologies in Medicine, Shahid Beheshti University of Medical Sciences, Tehran, Iran

3 Cellular and Molecular Biology Research Center, Shahid Beheshti University of Medical Sciences, Tehran, Iran

4 Proteomics Research Center, Shahid Beheshti University of Medical Science, Tehran, Iran

5 Department of Tissue Engineering and Applied Cell Sciences, School of Advanced Technologies in Medicine, Shahid Beheshti University of Medical Sciences, Tehran, Iran rigidity, dementia, and difficulties in secretion clearance from lungs, respectively (Ferini-Strambi and Salsone 2021). Since the number of patients with neurodegenerative disorders and COVID-19 who have been studied is small, the results of these studies are sometimes inconsistent and not generalizable (Del Prete et al. 2021; Yu et al. 2021).

Finding a more in-depth insight into biological processes and pathways involved in neurological manifestations of COVID-19 seems necessary. Only two high-throughput datasets are available in the gene expression omnibus database (GEO, http://www.ncbi.nlm.nih.gov/geo) (GSE157424 and GSE159812) so far, which has attempted to analyze the SARS-CoV-2 infection impacts on neural cells, and no highthroughput data on neurons treated with SARS-CoV-2 are available in the ArrayExpress databank (https://www.ebi.ac. uk/arrayexpress/).

Several hypotheses have been proposed about the routes of SARS-CoV-2 neuroinvasion, including neuronal retrograde, hematogenous, glymphatic rout, and trans-synaptic (Fig. 1). In the retrograde neuronal pathway, the virus can penetrate from the respiratory tract to the central nervous system (CNS) through the olfactory bulb (Desforges et al. 2019; Baig et al. 2020; Li et al. 2020). Damage of the olfactory endothelium could be related to anosmia or hyposmia symptoms. In the hematogenous route, the virus uses the bloodstream to reach cerebral circulation, damages endothelial cells of the blood-brain-barrier (BBB), and enters the CNS. Other respiratory viruses can also contaminate leukocytes and spread to the brain through cerebral circulation (Hamming et al. 2004; Desforges et al. 2019; Li et al. 2020). Glymphatic routs are physiological routes connected to the cervical and olfactory lymphatic vessels. The virus can use it to reach the CNS (Louveau et al. 2015; Iroegbu et al. 2020). The last suggested route is the trans-synaptic exchange of virus particles from peripheral nerves to the CNS (Li et al. 2020). Moreover, hyper-inflammation and hyper-coagulation can increase BBB permeability and entrance of the viral particles to the brain, which results in local hypoxia, ischemic infarcts, and BBB breakdown (Battaglini et al. 2020; Song et al. 2020). 

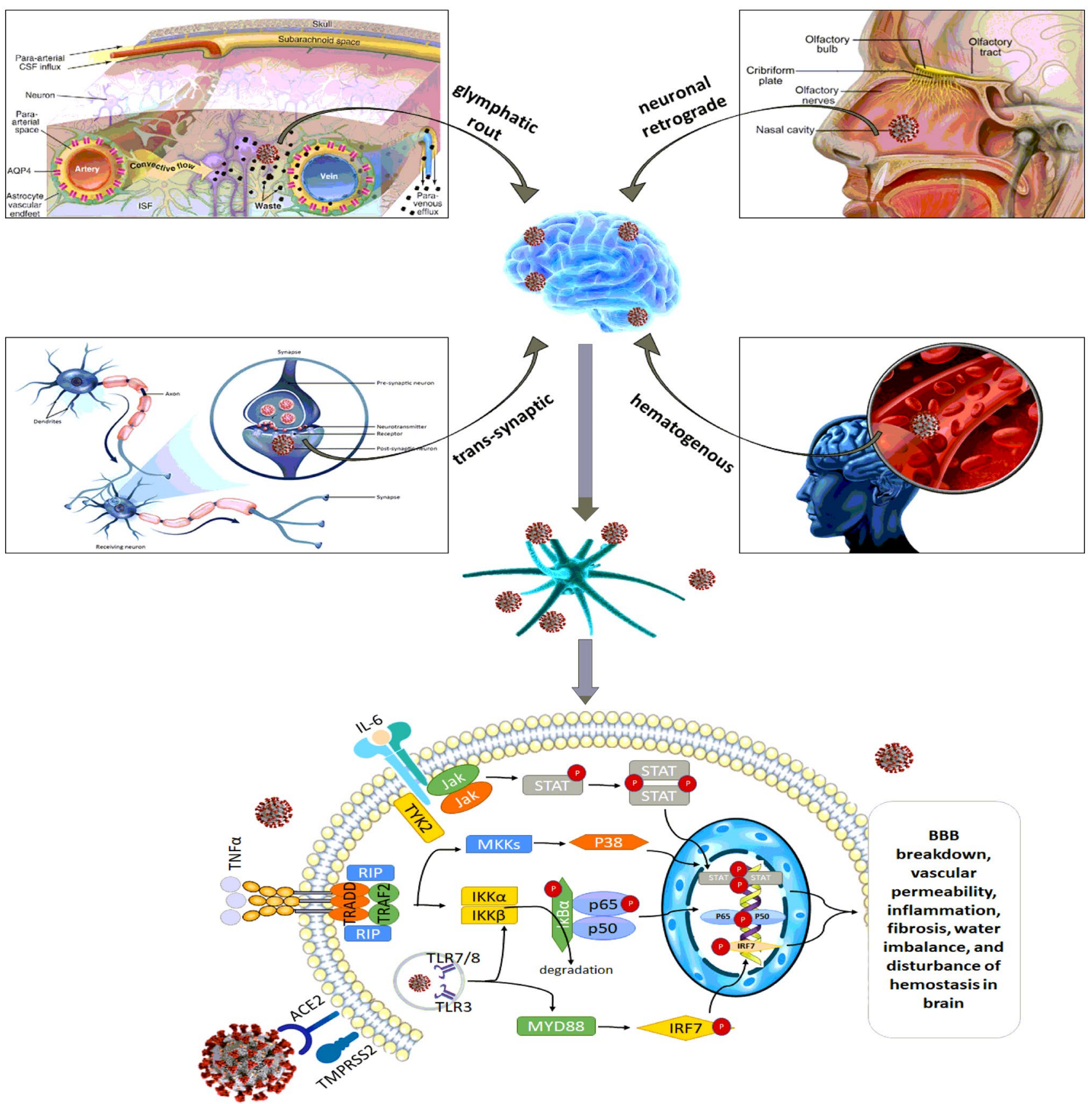

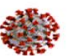

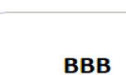

breakdown,

vascular

permeability,

inflammation,

fibrosis, water

imbalance, and

disturbance of

hemostasis in

brain

Fig.1 Routes and biochemical pathways involved in SARS-CoV-2 neuroinvasion

In the CNS, microglial cells function similarly to macrophages that respond to virus infection. Microglia inductively express the pattern-recognition receptors (PRRs) that recognize viral pathogen-associated molecular patterns (PAMPs) (Li et al. 2004). After receptor-mediated endocytosis of SARS-CoV-2, Toll-like receptor (TLR) 7/8 and TLR 3 can recognize viral RNA and Double-stranded RNA intermediates, respectively (Kircheis et al. 2020). Then inflammatory cascades initiate by activating the IFN and NF-kB signaling pathways (Sabroe et al. 2008; Totura et al. 2015). In viral infection of the human central nervous system (CNS), type I IFN (IFN- $\alpha$ and IFN- $\beta$ ) is produced by infected cells, and type-II IFN (IFN $\gamma$ ) is expressed by activated immune cells (Kulkarni et al. 2017). In the NF-kB pathway, activation of IKK $\alpha$ and IKK $\beta$ leads to phosphorylation and ubiquitination of the cytoplasmic inhibitor factor IкB $\alpha$. Then p50/p65 dimers are released and translocate to the nucleus. NF-kB dimers can regulate gene expression by binding to $\mathrm{kB}$ sites in promoter regions of proinflammatory cytokines such as IL- 6 , TNF- $\alpha$, IL-1 $\beta$, and IL-8 (Catanzaro et al. 2020; Kircheis et al. 2020). The virus is 
also recognized by cytoplasmic NOD-like receptors (NLRP3) that is a PAMP sensor. After binding to the virus, it forms an inflammasome complex with caspase-1 (Casp-1) and cleaves pro-IL-1 $\beta$ and pro-IL-18 to their mature forms (Battagello et al. 2020; Guadarrama-Ortiz et al. 2020). Hyper-cytokinemia plays an essential role in systemic inflammatory response syndrome (SIRS) that can cause brain damage (Catanzaro et al. 2020). TNF binds to its receptors and activates TNF receptor-associated factor (TRAF) and receptor-interacting protein (RIP) that leads to induce NF-kB and MAPK pathways (Battagello et al. 2020). From three prominent families of mitogen-activated protein kinases (MAPKs) in mammalians (ERKs, JNKs, and p38 MAPKs), some reports showed the p38s involvement in SARS-CoV-2 infection. Proinflammatory factors can induce the p38MAPK pathway, and in turn, it can regulate immune responses. Increased MAPK signaling activity can regulate neuronal survival and homeostasis in the CNS (Feng et al. 2019; Grimes and Grimes 2020). In the JAK/STAT pathway, IL-6 binding to IL-6 receptor mediate JAK proteins phosphorylation, leading to activation of STAT proteins. Phosphorylated STATs dimerize and translocate to the nucleus, where they act as transcription factors to regulate gene expression (O'Shea et al. 2015). SARS-CoV-2 infection down-regulates ACE2 expression, similar to SARS Coronavirus. Decreased level of ACE2 changes the balance of Ang-II / Ang-I and causes inflammation and vascular permeability (Kuba et al. 2005; Gheblawi et al. 2020). Accumulated Ang-II binds to Angiotensin-II type-1 receptor (AT1R) and induces inflammation and fibrosis via the JACK-STAT pathway. Since the Renin-Angiotensin system plays a vital role in regulating water balance and blood pressure in the brain, an increase in Ang-II level may lead to encephalitis and meningitis (Xiao et al. 2013; Groß et al. 2020). Pathways involved in SARS-CoV-2 neuroinvasion are summarized in Fig. 1.

Direct and indirect effects of SARS-CoV-2 on the brain endothelium (especially BBB) and vascular permeability, in addition to hyper-inflammation, hyper-coagulation, and disturbance of hemostasis in the brain, can justify CNS injury in COVID-19 patients. Some of these injuries are encephalopathy, encephalitis, encephalomyelitis, meningoencephalitis, demyelination, hypoxic injury, and hydrocephalus (Kotfis et al. 2020; Moriguchi et al. 2020; Paterson et al. 2020; Zanin et al. 2020).

Funding The research leading to these results received funding from the School of Advanced Technologies in Medicine of Shahid Beheshti University of Medical Sciences, under Grant Agreement No. 28318.

\section{Declarations}

Ethical Approval Approval was obtained from the ethics committee of Tehran University of medical science (Ethics approval number: IR.TUMS.TIPS.REC.1400.011).
Conflict of Interest Authors declare no conflict of interest.

\section{References}

Baig AM, Khaleeq A, Ali U, Syeda H (2020) Evidence of the COVID19 virus targeting the CNS: tissue distribution, host-virus interaction, and proposed neurotropic mechanisms. ACS Chem Neurosci 11(7):995-998

Battagello DS, Dragunas G, Klein MO, Ayub ALP, Velloso FJ, Correa RG (2020) Unpuzzling COVID-19: tissue-related signaling pathways associated with SARS-CoV-2 infection and transmission. Clin Sci (lond) 134(16):2137-2160

Battaglini D, Brunetti I, Anania P, Fiaschi P, Zona G, Ball L, Giacobbe DR, Vena A, Bassetti M, Patroniti N, Schenone A, Pelosi P, Rocco PRM, Robba C (2020) Neurological manifestations of severe SARS-CoV-2 infection: potential mechanisms and implications of individualized mechanical ventilation settings. Front Neurol 11(845)

Catanzaro M, Fagiani F, Racchi M, Corsini E, Govoni S, Lanni C (2020) Immune response in COVID-19: addressing a pharmacological challenge by targeting pathways triggered by SARSCoV-2. Signal Transduct Target Ther 5(1):84

Del Prete E, Francesconi A, Palermo G, Mazzucchi S, Frosini D, Morganti R, Coleschi P, Raglione LM, Vanni P, Ramat S, Novelli A, Napolitano A, Battisti C, Giuntini M, Rossi C, Menichetti C, Ulivelli M, De Franco V, Rossi S, Bonuccelli U, Ceravolo R, Tuscany Parkinson C-P (2021) Prevalence and impact of COVID19 in Parkinson's disease: evidence from a multi-center survey in Tuscany region. J Neurol 268(4):1179-1187

Desforges M, Le Coupanec A, Dubeau P, Bourgouin A, Lajoie L, Dubé M, Talbot PJ (2019) Human coronaviruses and other respiratory viruses: underestimated opportunistic pathogens of the central nervous system?. Viruses 12(1)

Feng Y, Fang Z, Liu B, Zheng X (2019) p38MAPK plays a pivotal role in the development of acute respiratory distress syndrome. Clinics 74

Ferini-Strambi L, Salsone M (2021) COVID-19 and neurological disorders: are neurodegenerative or neuroimmunological diseases more vulnerable? J Neurol 268(2):409-419

Gheblawi M, Wang K, Viveiros A, Nguyen Q, Zhong JC, Turner AJ, Raizada MK, Grant MB, Oudit GY (2020) Angiotensin-converting enzyme 2: SARS-CoV-2 receptor and regulator of the reninangiotensin system: celebrating the 20th anniversary of the discovery of ACE2. Circ Res 126(10):1456-1474

Grimes JM, Grimes KV (2020) p38 MAPK inhibition: A promising therapeutic approach for COVID-19. J Mol Cell Cardiol 144:63-65

Groß S, Jahn C, Cushman S, Bär C, Thum T (2020) SARS-CoV-2 receptor ACE2-dependent implications on the cardiovascular system: from basic science to clinical implications. J Mol Cell Cardiol 144:47-53

Guadarrama-Ortiz P, Choreño-Parra JA, Sánchez-Martínez CM, Pacheco-Sánchez FJ, Rodríguez-Nava AI, García-Quintero G (2020) Neurological aspects of SARS-CoV-2 infection: mechanisms and manifestations. Front Neurol 11(1039)

Hamming I, Timens W, Bulthuis ML, Lely AT, Navis G, van Goor H (2004) Tissue distribution of ACE2 protein, the functional receptor for SARS coronavirus. A first step in understanding SARS pathogenesis. J Pathol 203(2):631-637

Iroegbu JD, Ifenatuoha CW, Ijomone OM (2020) Potential neurological impact of coronaviruses: implications for the novel SARS-CoV-2. Neurol Sci 41(6):1329-1337

Kircheis R, Haasbach E, Lueftenegger D, Heyken WT, Ocker M, Planz $\mathrm{O}(2020) \mathrm{NF}-\kappa \mathrm{B}$ pathway as a potential target for treatment of critical stage COVID-19 patients. Front Immunol 11(3446) 
Kotfis K, Williams Roberson S, Wilson JE, Dabrowski W, Pun BT, Ely EW (2020) COVID-19: ICU delirium management during SARS-CoV-2 pandemic. Crit Care 24(1):176

Kuba K, Imai Y, Rao S, Gao H, Guo F, Guan B, Huan Y, Yang P, Zhang Y, Deng W, Bao L, Zhang B, Liu G, Wang Z, Chappell M, Liu Y, Zheng D, Leibbrandt A, Wada T, Slutsky AS, Liu D, Qin C, Jiang C, Penninger JM (2005) A crucial role of angiotensin converting enzyme 2 (ACE2) in SARS coronavirus-induced lung injury. Nat Med 11(8):875-879

Kulkarni A, Scully TJ, O’Donnell LA (2017) The antiviral cytokine interferon-gamma restricts neural stem/progenitor cell proliferation through activation of STAT1 and modulation of retinoblastoma protein phosphorylation. J Neurosci Res 95(8):1582-1601

Li Y, Fu L, Gonzales DM, Lavi E (2004) Coronavirus neurovirulence correlates with the ability of the virus to induce proinflammatory cytokine signals from astrocytes and microglia. J Virol 78(7):3398-3406

Li Z, Liu T, Yang N, Han D, Mi X, Li Y, Liu K, Vuylsteke A, Xiang H, Guo X (2020) Neurological manifestations of patients with COVID-19: potential routes of SARS-CoV-2 neuroinvasion from the periphery to the brain. Front Med 14(5):533-541

Liu K, Pan M, Xiao Z, Xu X (2020) Neurological manifestations of the coronavirus (SARS-CoV-2) pandemic 2019-2020. J Neurol Neurosurg Psychiatry 91(6):669-670

Louveau A, Smirnov I, Keyes TJ, Eccles JD, Rouhani SJ, Peske JD, Derecki NC, Castle D, Mandell JW, Lee KS, Harris TH, Kipnis J (2015) Structural and functional features of central nervous system lymphatic vessels. Nature 523(7560):337-341

Moriguchi T, Harii N, Goto J, Harada D, Sugawara H, Takamino J, Ueno M, Sakata H, Kondo K, Myose N, Nakao A, Takeda M, Haro H, Inoue O, Suzuki-Inoue K, Kubokawa K, Ogihara S, Sasaki T, Kinouchi H, Kojin H, Ito M, Onishi H, Shimizu T, Sasaki Y, Enomoto N, Ishihara H, Furuya S, Yamamoto T, Shimada S (2020) A first case of meningitis/encephalitis associated with SARS-Coronavirus-2. Int J Infect Dis 94:55-58

O'Shea JJ, Schwartz DM, Villarino AV, Gadina M, McInnes IB, Laurence A (2015) The JAK-STAT pathway: impact on human disease and therapeutic intervention. Annu Rev Med 66:311-328

Paterson RW, Brown RL, Benjamin L, Nortley R, Wiethoff S, Bharucha T, Jayaseelan DL, Kumar G, Raftopoulos RE, Zambreanu L, Vivekanandam V, Khoo A, Geraldes R, Chinthapalli K, Boyd E, Tuzlali H, Price G, Christofi G, Morrow J, McNamara P, McLoughlin B, Lim ST, Mehta PR, Levee V, Keddie S, Yong W, Trip SA, Foulkes AJM, Hotton G, Miller TD, Everitt AD, Carswell C, Davies
NWS, Yoong M, Attwell D, Sreedharan J, Silber E, Schott JM, Chandratheva A, Perry RJ, Simister R, Checkley A, Longley N, Farmer SF, Carletti F, Houlihan C, Thom M, Lunn MP, Spillane J, Howard R, Vincent A, Werring DJ, Hoskote C, Jäger HR, Manji H, Zandi MS (2020) f. t. U. Q. S. N. H. f. Neurology and N. C.-S. Group The emerging spectrum of COVID-19 neurology: clinical, radiological and laboratory findings. Brain 143(10):3104-3120

Reichard RR, Kashani KB, Boire NA, Constantopoulos E, Guo Y, Lucchinetti CF (2020) Neuropathology of COVID-19: a spectrum of vascular and acute disseminated encephalomyelitis (ADEM)like pathology. Acta Neuropathol 140(1):1-6

Sabroe I, Parker L, Dower S, Whyte M (2008) The role of TLR activation in inflammation. J Pathol 214(2):126-135

Song E, Zhang C, Israelow B, Lu-Culligan A, Prado AV, Skriabine S, Lu P, Weizman O-E, Liu F, Dai Y, Szigeti-Buck K, Yasumoto Y, Wang G, Castaldi C, Heltke J, Ng E, Wheeler J, Alfajaro MM, Levavasseur E, Fontes B, Ravindra NG, Van Dijk D, Mane S, Gunel M, Ring A, Jaffar Kazmi SA, Zhang K, Wilen CB, Horvath TL, Plu I, Haik S, Thomas J-L, Louvi A, Farhadian SF, Huttner A, Seilhean D, Renier N, Bilguvar K, Iwasaki A (2020) Neuroinvasion of SARS-CoV-2 in human and mouse brain. bioRxiv: 2020.2006.2025.169946

Totura AL, Whitmore A, Agnihothram S, Schäfer A, Katze MG, Heise MT, Baric RS (2015) Toll-like receptor 3 signaling via TRIF contributes to a protective innate immune response to severe acute respiratory syndrome coronavirus infection. mBio 6(3):e00638-00615

Valiuddin HM, Kalajdzic A, Rosati J, Boehm K, Hill D (2020) Update on neurological manifestations of SARS-CoV-2. West J Emerg Med 21(6):45-51

Xiao L, Haack KK, Zucker IH (2013) Angiotensin II regulates ACE and ACE2 in neurons through p38 mitogen-activated protein kinase and extracellular signal-regulated kinase 1/2 signaling. Am J Physiol Cell Physiol 304(11):C1073-1079

Yu Y, Travaglio M, Popovic R, Leal NS, Martins LM (2021) Alzheimer's and Parkinson's diseases predict different COVID-19 outcomes: A UK biobank study. Geriatrics 6(1):10

Zanin L, Saraceno G, Panciani PP, Renisi G, Signorini L, Migliorati K, Fontanella MM (2020) SARS-CoV-2 can induce brain and spine demyelinating lesions. Acta Neurochir (wien) 162(7):1491-1494

Publisher's Note Springer Nature remains neutral with regard to jurisdictional claims in published maps and institutional affiliations. 